SOI: $1.1 / \mathrm{TAS} \quad$ DOI: $10.15863 / \mathrm{TAS}$

\section{International Scientific Journal} Theoretical \& Applied Science

\author{
p-ISSN: 2308-4944 (print) e-ISSN: 2409-0085 (online) \\ Year: 2015 Issue: 10 Volume: 30 \\ Published: $30.10 .2015 \quad$ http://T-Science.org
}

Inna Aleksandrovna Serebryanik

Candidate of Technical Sciences, associate professor of the Department of World economy, Irkutsk National Research Technical University, Russia nasamolet@yandex.ru

Svetlana Valeryevna Fedorova Candidate of Technical Sciences, associate professor of the Department of World economy, Irkutsk national - research technical university, Russia $\underline{\text { fsta@istu.irk.ru }}$

SECTION 12. Geology. Anthropology.

Archaeology.

\title{
PROCESSING MICA IN SIBERIA: HISTORICAL ASPECT
}

Abstract: The article discusses the history of development processing of mica by the example of Siberian cities such as Irkutsk, Nizhneudinsk, Taishet.

Key words: mica, mica processing, mica factory, Siberia.

Language: Russian

Citation: Serebryanik IA, Fedorova SV (2015) PROCESSING MICA IN SIBERIA: HISTORICAL ASPECT. ISJ Theoretical \& Applied Science 10 (30): 20-23.

Soi: http://s-o-i.org/1.1/TAS-10-30-6 Doi: crossef http://dx.doi.org/10.15863/TAS.2015.10.30.6

\section{СЛЮДОПЕРЕРАБОТКА В СИБИРИ: ИСТОРИЧЕСКИЙ АСПЕКТ}

Аннотация: В статье рассмотрена история развития слюдопереработки на примере городов Сибири, таких как Иркутск, Нижнеудинск, Тайшет.

Ключевые слова: слюда, переработка слюды, слюдяная фабрика, Сибирь.

В СССР молотая слюда сухого помола чаще всего применялась для изготовления электродов, органосиликатных материалов. Существовали и более узкие сферы применения. Что касается слюды мокрого помола, то ее только начинали использовать на предприятиях, где изготавливалась лакокрасочная продукция.

История Иркутской слюдяной фабрики берет свое начало в марте 1929 года. Это год создания мастерской по обработке слюды «Слюдорезки». Мастерская размещалась в старом купеческом амбаре на улице Желябова. Ее площадь составляла $50 \mathrm{M}^{2}$ и работало там 126 человек. Труд в «Слюдорезке» был ручной.

Отсутствие необходимой квалификации работников, а также механизации, приводило к тому, что производство часто простаивало, а себестоимость готовой продукции была чрезвычайно высока. Вскоре на недочеты в работе обратили внимание руководящие органы. Было принято решение строительства слюдоперерабатывающей фабрики, где бы устранялись недостатки отсутствия исследовательско-разведочной работы, неравномерных поставок сырья, отсутствия квалификации у работников. В 1930 году мастерскую переименовали в фабрику имени 8
Марта. С этого времени фабрика начинает стремительно развиваться.

В 1933 году в Иркутской фабрике построен новый цех щипки слюды, в 1934 году - цех помола. Уже в 1935 году был построен главный производственный корпус вместе с электростанцией. Если в начале в мастерской походила лишь первичная обработка сырья, то уже к 1940-му году фабрика уже выпускала готовую продукцию. Военные годы - это период интенсивной работы фабрики. Работа шла в три смены. Связано это было с тем, что слюда имела стратегической значение для оборонной промышленности страны. С 1939 года, когда началось обновление боевой авиации, связанное со Второй мировой войной, были перестроены многие производства. В этот период резко возрастает спрос на слюду. А Иркутская область оказывается тем самым местом, где можно добывать много слюды, как темной, так и светлой, более качественной [8].

Изначально Иркутская слюдяная фабрика подчинялась «Сибслюдтресту», который был создан в 1927 году. Все месторождения слюды были переданы в его ведение. В 1930 году трест был преобразован в «Союзслюда», территориально находящийся в Иркутске. В 
1927-1928 годах трест добывал 82\% от всей добычи слюды в СССР, в начале 1930-х годов $86,7 \%$ по данным ГАНИИО, Государственного архива новейшей истории Иркутской области). При этом план по обработке слюды не выполнялся. В 1931 году трест принял решение открыть филиал фабрики в Нижнеудинске. Начиналось все также, как и в Иркутске, с небольшой мастерской со штатом в 30 человек. Конечным продуктом мастерской была щипаная слюда-флогопит. Труд по-прежнему остается ручной. При этом объемы производства растут, штат увеличивается. В 1932 году он уже составляет 237 человек. С 1937 года было освоено производство слюды щипаной, обрезной, стержневой.

К середине 1930-х гг. область была важнейшей сырьевой базой слюдяной промышленности СССР [11]. В военное время на территории области работали три крупные слюдяные фабрики: в Иркутске, Нижнеудинске, Слюдянке.
В 1955 году от Нижнеудинской слюдяной фабрики открыли цех в Слюдянке. Уже в 1957 году его передали Иркутской слюдяной фабрике. У данного цеха №5 сложная судьба. В 1971 году его перепрофилировали в швейный. От штата в 500 человек осталось 250. Некоторые слюдянщицы (основной штат всегда был женский) смогли переквалифицироваться, остальные уволились. Однако уже в 1974 году цех снова перевели под управление Иркутской слюдяной фабрики им. 8 марта. Слюда попрежнему оставалась востребованным продуктом. Работницы вспоминают, что на фабрике висел плакат «И для полета в космос нужна слюда» [7].

С 1964 года Нижнеудинская фабрика производит готовый продукт на основе слюды микалекс (композитный материал на основе слюды и стекла).

В 2011 году Нижнеудинской фабрике исполнилось 80 лет. Сегодня на ней не ведется никакого производства (рисунок 1).

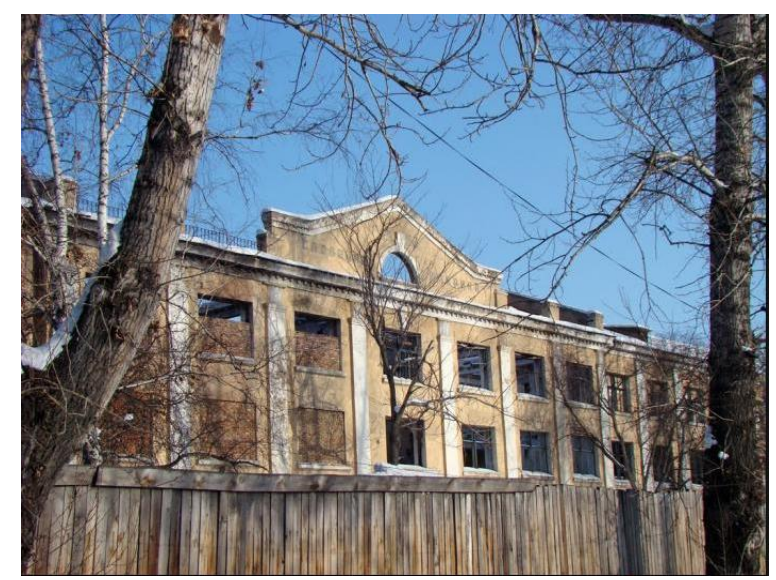

\section{Рисунок 1 - Современный вид Нижнеудинской слюдянитовой фабрики.}

В 60-х годах начинает широко внедряться автоматика. Новейшее оборудование позволяет фабрике увеличивать выпуск радиодеталей и конденсаторной слюды. За 1967-1971 гг. производство радиодеталей возросло на 28\%, конденсаторной слюды - на $26 \%$. В производстве начинают использовать вторичное сырье. Это снизило себестоимость продукции и увеличило объем производства на 7,8\% [2].

«Иркутская слюдяная фабрика им. 8 марта» стала самым крупным центром слюдопереработки. Сегодня этот символ советской эпохи канул в лету.

После распада СССР начался затяжной кризис. Спрос на слюду достиг дна. Предприятия стали завозить слюду из Индии. Это привело к закрытию предприятий на севере Иркутской области. Один за другим стали исчезать горняцкие поселки. Только в 2015 году закрылись Согдиондон и Горно-Чуйский.

Слюдяное производство в Тайшете не стало полноценной подотраслью слюдяной промышленности [1]. Работало только одно предприятие, занятое в переработке сырья. Потому можно было говорить лишь о неполном по циклу слюдяном производстве. Тайшетский слюдяной цех не производил готовой продукции. Он не являлся самостоятельной хозяйственной единицей, а лишь структурным подразделением Нижнеудинской слюдфабрики.

Слюдяное производство в Тайшете было сформировано в силу ряда причин:

1. близость от Тайшета месторождений слюды и существующих слюдяных фабрик;

2. наличие свободной рабочей силы в городе; 
3. наличие опыта переработки слюды мелкими кустарными предприятияи (промартелями).

Однако сегодня можно говорить о возрождении спроса на слюду, в таких отраслях, как автомобилестроение (резинотехнические изделия, лакокрасочные материалы), строительство (отделочные материалы) и многие другие.
Сегодня в Иркутской области работает группа компаний «Сибирские минералы». В нее входит несколько компаний, занятых в процессах добычи и переработки слюды мусковит МамскоЧуйского слюдяного месторождения. Предприятие предлагает, как листовую слюду, так и различные детали (рисунок 2), а также обрезную слюду, слюдяные пластины СМОГ (рисунок 3).

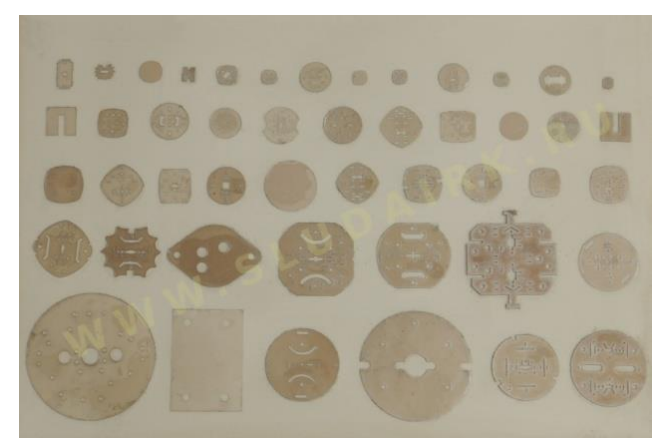

Рисунок 2 - Детали из слюды, производимые группой компаний «Сибирские минералы».

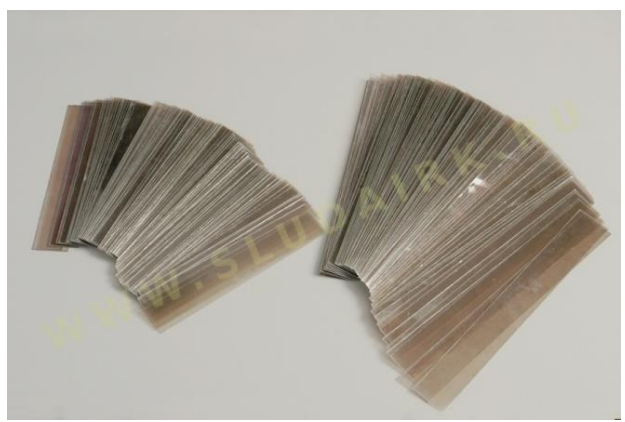

Рисунок 3 - слюдяные пластины СМОГ, производимые группой компаний «Сибирские минералы».

Забойный сырец, который содержит 95\% слюды, обрабатывается в месте добычи, так как его перевозка в город Иркутск экономически нецелесообразно. Забойный сырец обрабатывается в специализированном цехе непосредственно в месте проведения горных работ.

После получения промышленной слюды, ее отправляют в город Иркутск в собственные слюдообработочные цеха. Здесь происходит ее дальнейшая, глубокая обработка, а в дальнейшем производство слюдяных изделий.

Доставка компания осуществляет автомобильным транспортом. В период межсезонья, когда дороги становятся непроходимы - авиационным транспортом.

В Иркутске сырье перерабатывается в слюдяные подборы - слюдяной полуфабрикат, из которого затем производятся различные виды слюдяных изделий. Подборы могут быть колотые - без удаления краевых дефектов и очищенные или полуочищенные - с удалением полностью или частично краевых дефектов путем их среза.

Предприятие использует, как традиционные технологии, так и новые, которые позволяют получить продукт высокого класса качества. Вся производимая продукция проходит проверку на соответствие техническим требованиям.

Сегодня можно говорить о том, что экономический кризис и проблемы, связанные с падением рубля, заставляют некоторых специалистов говорить о необходимости возобновления добычи слюды в Иркутской области. Специалисты отмечают, что наметились положительные тенденции в развитии российской электротехнической промышленности, которая могла бы снова стать крупным потребителем слюды. Мамско-Чуйкая слюдоносная провинция является сегодня крупнейшей в мире. Возможно, у данного района появится будущее. 


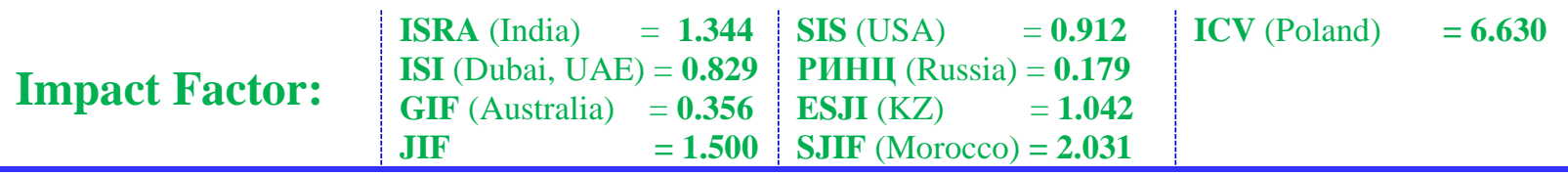

\section{References:}

1. (2015) Arhiv gazety Vlast' truda: [sajt]. Available: http://ellib.library.isu.ru/vlast truda/index.php

2. Volobuev GT (2009) Centr sljudjanogo proizvodstva v Krasnojarskom krae // Sibirskij subjetnos: kul'tura, tradicii, mental'nost': materialy V Vserossijskoj nauchnoprakticheskoj Internet-konferencii na sajte sibsubethnos.narod.ru, 15 janvarja - 15 maja 2009 goda / Federal. agentstvo po obrazovaniju, GOU VPO "Krasnojar. gos. ped. un-t im. V. P. Astaf'eva". - Krasnojarsk : KGPU im. V. P. Astaf'eva, 2009. pp. 65-78 .

3. (2000) Gody i ljudi sljudjanoj Mamy: (Istorija Mamsko-Chujskoj jekspedicii) / M. I. Verhoturov [i dr.]; Irkut. gos. tehn. un-t. Irkutsk: Izd-vo IrGTU, 2000. - 324 p.

4. Dubenskij AM, Leonov CB, Bajnblat JS (1985) Obogashhenie listovyh sljud, Irkutsk: Izd-vo Irkut.un-ta, 1985. - $184 \mathrm{p}$.

5. Dubovik MM, Libman JP (1966) Dve zhizni chudesnogo kamnja: Iz istorii sljudjanogo promysla v Rossii. - Moscow: Nedra, 1966. $-188 \mathrm{pp}$.

6. Dulov AV (1990) Pamjatniki istorii i kul'tury Priangar'ja. - Bimkom, 1990. - 288 p.

7. (2013) O truzhenicah ceha fabriki imeni 8 Marta v Sljudjanke. //gazeta "Sljudjanka" №10(53) ot 8 march 2013.

8. Pahomova NV (2015) Oboronnaja promyshlennost' Vostochnoj Sibiri v gody Velikoj Otechestvennoj vojny 1941-1945 gg. Monografija. Sibirskij federal'nyj universitet. OOO «Prospekt», 2015.

9. (1928) Pervyj Sibirskij kraevoj nauchnoissledovatel'skij sezd: doklady sekcii «Nedra». T. II. Novosibirsk, 1928.

10. Petrov VP (1978) 'Rasskazy o treh neobychnyh mineralah' - Moskva: Nedra, 1978 - p.176.

11. Prjanishev BG (2001) Irkutskaja sljudjanaja fabrika v 1930-h gg. //Vestnik Tomskogo gosudarstvennogo universiteta - №2(14) 2001. pp.124-126. 